\title{
Kinetics and equilibria for the axial ligation of bromomethyl (aqua)cobaloxime with pyridines - Isolation characterization and DNA binding
}

\author{
KOTHA LAXMA REDDY, K ASHWINI KUMAR, N RAVI KUMAR REDDY, \\ PENUMAKA NAGABABU, A PANASA REDDY and S SATYANARAYANA* \\ Department of Chemistry, Osmania University, Hyderabad 500007 \\ e-mail: ssnsirasani@yahoo.com
}

MS received 18 August 2007; revised 6 April 2009; accepted 8 July 2009

\begin{abstract}
The kinetics and equilibria for the axial ligation of pyridine and substituted pyridines to bromomethyl(aqua)cobaloxime have been measured spectrophotometrically in aqueous solutions of ionic strength $1.0 \mathrm{M}(\mathrm{KCl})$ at $25^{\circ} \mathrm{C}$ as a function of $p \mathrm{H}$. The binding constants and rate of formation increase in the order $4-\mathrm{NH}_{2} \mathrm{Py}>4-\mathrm{EtPy}>4-\mathrm{MePy}>\mathrm{Py}>2-\mathrm{NH}_{2} \mathrm{Py}>2-\mathrm{EtPy}$. The data have been interpreted based on the basicity of the ligand, $\pi$-back bonding from $\mathrm{Co}$ (III) $\rightarrow \mathrm{L}$ and hard and soft interactions. The rate of substitution of $\mathrm{H}_{2} \mathrm{O}$ varies with the $\mathrm{pKa}$ of the incoming ligand, thus establishing the existence of nucleophilic participation of the ligand in the transition state. We have investigated the DNA binding of bromomethyl(aqua)cobaloxime with DNA. Bromomethyl(ligand)cobaloximes were isolated and characterized by elemental analysis, IR and $\operatorname{NMR}\left({ }^{1} \mathrm{H},{ }^{13} \mathrm{C}\right)$ spectra.
\end{abstract}

Keywords. Cobaloximes; kinetics and equilibria; DNA-binding.

\section{Introduction}

Cobaloximes are complexes containing the bis (dimethylglyoximato) cobalt(III) moiety, $\mathrm{Co}(\mathrm{DH})_{2}^{+}$ ( $\mathrm{DH}=$ mono anion of dimethylglyoxime). These simulate the reactions of vitamin- $\mathrm{B}_{12}$ and accepted as coenzyme $\mathrm{B}_{12}$ model compounds. Homolytic cleavage of the Co-C bond is the key step in the mechanism of action of many enzymes. ${ }^{1}$ It is widely believed that structural and conformational changes in coenzyme $\mathrm{B}_{12}$ lead to acceleration in $\mathrm{Co}-\mathrm{C}$ bond cleavage rates. ${ }^{2,3}$ The study of simple models of the $\mathrm{B}_{12}$ coenzyme, such as the cobaloximes, has furnished a significant amount of data ${ }^{4,5}$ that have provided a foundation for understanding the behaviour of cobalamins. ${ }^{6}$ Randaccio et al. ${ }^{7-9}$ compared the properties of rhodoximes and cobaloximes on the basis of electronic and steric effects. These studies were useful in understanding the mechanism of $\mathrm{Co}-\mathrm{C}$ bond cleavage in the vitamin $\mathrm{B}_{12}$ coenzyme.

Since binding of cobaloximes is closely related to the structural and binding characteristics of corrin systems involved in biological mechanisms and in

*For correspondence continuation of our work, ${ }^{10-13}$ we report here the isolation of bromomethyl(ligand) cobaloximes, equilibria and kinetics of the axial ligation of the bromomethyl(aqua) cobaloximes with pyridine and substituted pyridines. We have also investigated the interaction of bromomethyl cobaloxime with $\mathrm{CT}$ DNA.

\section{Materials and methods}

Pyridine, 4-Amino Pyridine, 4-Ethyl Pyridine, 4-Methyl Pyridine, 2-Amino Pyridine and 2-Ethyl Pyridine were obtained in highest purity from Acros. $\mathrm{KC} 1$, HPLC grade methanol, acetic acid, $\mathrm{HCl}$, phosphoric acid, formic acid were obtained from Fluka. Dipotassium hydrogen phosphate, potassium dihydrogen phosphate, potassium phosphate, tris (hydroxymethyl)aminomethane (Tris), sodium acetate, potassium hydroxide were obtained from Acros. Double distilled, deionized water was used throughout.

To maintain appropriate $p \mathrm{H} 0 \cdot 2 \mathrm{M}$ buffers of $\mathrm{HCl}$ $(0-1.5 p \mathrm{H}), \mathrm{KH}_{2} \mathrm{PO}_{4}$ and $\mathrm{H}_{3} \mathrm{PO}_{4}(2.0 p \mathrm{H}), \mathrm{HCOOH}$ and $\mathrm{KOH}(2.5-3.0 p \mathrm{H}), \mathrm{CH}_{3} \mathrm{COOH}$ and $\mathrm{CH}_{3} \mathrm{COONa}$ $(3.5-5.5 p \mathrm{H}), \mathrm{K}_{2} \mathrm{HPO}_{4}$ and $\mathrm{KH}_{2} \mathrm{PO}_{4}(6 \cdot 0-8 \cdot 0 p \mathrm{H})$, 
Tris and $\mathrm{HCl}(8 \cdot 5-9 \cdot 0 p \mathrm{H}), \mathrm{K}_{2} \mathrm{HPO}_{4}$ and $\mathrm{K}_{3} \mathrm{PO}_{4}$ $(9.5-11.5 \mathrm{pH})$ are used.

Alkyl(aqua)cobaloximes were prepared by the procedure of Brown et al. ${ }^{14}$ All manipulations were performed under minimal illuminations due to photolability of carbon-cobalt bond. ${ }^{6}$ These alkyl (aqua)cobaloximes are photolabile, particularly in solution. $p \mathrm{H}$ measurements were made with a Digisun digital $p \mathrm{H}$ meter equipped with a combined glass electrode. The electrode was standardized at two $p \mathrm{H}$ values $(p \mathrm{H}=4$ and $p \mathrm{H}=9 \cdot 2)$ with standard buffer solutions. UV and visible spectra were recorded on a Hitachi U-3410, the sample compartment of which is provided with a thermostat and the concentrations of bromomethyl(aqua)cobaloxime $(0.001 \mathrm{M})$ was fixed at $436 \mathrm{~nm}$. For axial ligation single wavelength measurements were made on Elico single beam spectrophotometer SL 171 model. The sample compartment of which was thermostated at $25 \pm 0 \cdot 1^{\circ} \mathrm{C}$.

$\left[\mathrm{BrCH}_{2} \mathrm{Co}(\mathrm{DH})_{2} \mathrm{~L}\right]$ complexes were isolated by mixing $1: 3$ ratio of bromomethyl (aqua) cobaloxime and the desired base ligand (L) in ethanol. This mixture was heated at $40-50^{\circ} \mathrm{C}$ by constant stirring for $1-2 \mathrm{~h}$. Then added minimum amount of distilled water to the above solution to get the precipitation and allowed it to settle. The resulting precipitate of yellow powder was filtered, washed with distilled water, 95\% ethanol and ether and dried in vacuo. Yields were $70-80 \%$. ${ }^{1} \mathrm{H}$ NMR spectra were recorded on varian Gemini $200 \mathrm{MHz}$ NMR spectrometer. Samples were prepared by dissolving in DMSO- $d_{6}$. Infrared spectra were obtained on Perkin Elmer FTIR-1605 spectrometer using $\mathrm{KBr}$ pellets. The molar conductivities of $0.001 \mathrm{M}$ solution of the complexes in methanol show that they are nonelectrolytes.

\section{Equilibrium measurements}

Apparent binding constant $\left(K_{\text {app }}\right)$ values were determined by spectrophotometric measurements at $436 \mathrm{~nm}$ for the axial ligation of bromomethyl (aqua)cobaloxime, as a function of $p \mathrm{H}$. In a $3 \mathrm{ml}$ cuvette solutions containing $\left[\mathrm{CH}_{2} \mathrm{BrCo}(\mathrm{DH})_{2}\left(\mathrm{H}_{2} \mathrm{O}\right)\right]$, an appropriate buffer $(0.2 \mathrm{M})$ to maintain $p \mathrm{H}, \mathrm{KCl}$ to maintain ionic strength $(1.0 \mathrm{M})$ and varying concentrations of ligand were taken in a cell block maintained at $25 \pm 0 \cdot 1{ }^{\circ} \mathrm{C}$. Solutions were allowed to equilibrate at $25^{\circ} \mathrm{C}$ in the spectrophotometer cell block for at least $15 \mathrm{~min}$ prior to addition of cobaloxime.
Final absorbance readings were taken after equilibrium was established as indicated by the time independence of the readings. For such experimental set-ups, at a given $p \mathrm{H}(1)$ is applied.

$$
\Delta A=\Delta A_{\max }[\mathrm{L}]_{\mathrm{f}} /\left(1 / K_{\mathrm{eq}}+[\mathrm{L}]_{\mathrm{f}}\right),
$$

where $\Delta A$ is the absolute value for difference in absorbance between solutions containing cobaloxime and added ligand (L) and solutions containing only cobaloxime at the same concentration. $\Delta A_{\max }$ is the maximum absorbance change thus obtained at high [L] at which the aqua complex is completely converted to the product. The data were analysed ${ }^{15}$ by a leastsquares fit to the rearranged form of (1) to give (2).

$$
\begin{aligned}
& \Delta A=\Delta A_{\max }-\left\{1 / K_{\mathrm{eq}} \Delta A / \mathrm{L}_{\mathrm{f}}\right\}, \\
& {[\mathrm{L}]_{\mathrm{f}}=[\mathrm{L}]_{\mathrm{tot}}-\left(C_{\mathrm{T}} \Delta A / \Delta A_{\mathrm{max}}\right) .}
\end{aligned}
$$

$[\mathrm{L}]_{\mathrm{f}}$ is calculated from (3) using measured value of $\Delta A_{\max }$, where $[\mathrm{L}]_{\mathrm{tot}}$ is the total concentration of added ligand and $C_{\mathrm{T}}$ is the total concentration of cobaloxime. $\Delta A$ is plotted as a function of $\Delta A /[\mathrm{L}]_{\mathrm{f}}$ and the slope is $-1 / K_{\text {eq }}$.

\subsection{Kinetic measurements}

Kinetic measurements were made for the binding of ligand to bromomethyl(aqua)cobaloxime. For each ligand $\mathrm{L}$, at various $p \mathrm{H}$, first order rate constants $\left(k_{\text {obs }}\right)$ was determined from the absorbance measurements at the same wavelength used for $K_{\mathrm{eq}}$ determinations under pseudo-first order condition with $\mathrm{L}$, in at least 10 fold excess over cobaloxime concentration $\left(0.00125 \mathrm{~mol} \mathrm{dm}^{-3}\right)$.

Progress of the reaction was monitored by measurements of the change in the absorbance on addition of bromomethyl(aqua)cobaloxime to a $3 \mathrm{ml}$ cuvette which contained known concentration of ligand at appropriate $p \mathrm{H}$ in the thermostated $(25 \pm$ $0 \cdot 1{ }^{\circ} \mathrm{C}$ ) cell compartment.

First order rate constants $\left(k_{\text {obs }}\right)$ were obtained by least-squares fit of the data to (4)

$$
\ln \left(A_{\mathrm{t}}-A_{\alpha}\right)=k_{\text {obs }} t .
$$

where $A_{\mathrm{t}}$, is the absorbance at time $t$ and $A_{\alpha}$ is the final absorbance.

Second order rate constants, $k_{\text {on }}$, at a given $p \mathrm{H}$ for a given ligand were obtained from the slopes of least squares fits of the data to (5) 
Table 1. $1 \mathrm{R}^{*}$ and ${ }^{1} \mathrm{H} \mathrm{NMR}^{\#}$ spectral data for bromomethyl (ligand)cobaloximes $-\left[\mathrm{BrCH}_{2} \mathrm{Co}(\mathrm{DH})_{2} \mathrm{~L}\right]$.

\begin{tabular}{|c|c|c|c|c|c|c|c|c|}
\hline $\begin{array}{l}\text { Sl. } \\
\text { no. }\end{array}$ & $\begin{array}{c}\text { Complex } \\
{\left[\mathrm{BrCH}_{2} \mathrm{Co}(\mathrm{DH})_{2} \mathrm{~L}\right]} \\
\text { where } \mathrm{L}=\end{array}$ & $\begin{array}{c}\mathrm{Co}-\mathrm{N} \\
(\mathrm{N} \text { of } \mathrm{L})\end{array}$ & $\begin{array}{c}v \mathrm{Co}-\mathrm{N} \\
(\mathrm{N} \text { of } \mathrm{DH})\end{array}$ & $v \mathrm{~N}-\mathrm{O}$ & $v \mathrm{CH}_{3}$ & $v \mathrm{C}=\mathrm{N}$ & $v \mathrm{H}-\mathrm{O} \ldots \mathrm{H}$ & ${ }^{1} \mathrm{H}$ NMR Data \\
\hline 1 & $\begin{array}{l}\mathrm{H}_{2} \mathrm{O} \\
\text { Water }\end{array}$ & - & $510 \cdot 0$ & $\begin{array}{l}1085 \cdot 0 \\
1231 \cdot 0\end{array}$ & $\begin{array}{l}1376 \cdot 0 \\
1438 \cdot 0\end{array}$ & $1572 \cdot 0$ & $1774 \cdot 0$ & $2 \cdot 26(s), 3 \cdot 38(s)$ \\
\hline 2 & $\begin{array}{l}\mathrm{C}_{5} \mathrm{H}_{5} \mathrm{~N} \\
\text { Pyridine }\end{array}$ & $452 \cdot 6$ & $514 \cdot 6$ & $\begin{array}{l}1088 \cdot 5 \\
1234 \cdot 0\end{array}$ & $\begin{array}{l}1366 \cdot 4 \\
1442 \cdot 9\end{array}$ & $1559 \cdot 9$ & $1735 \cdot 0$ & $\begin{array}{l}2 \cdot 18(s), 3 \cdot 50(s), 7 \cdot 42(t) \\
7 \cdot 85(m), 8 \cdot 50(d)\end{array}$ \\
\hline 3 & $\begin{array}{l}\mathrm{C}_{5} \mathrm{H}_{4} \mathrm{~N}-\mathrm{CH}_{3} \\
\text { 4-Methylpyridine }\end{array}$ & $456 \cdot 4$ & $515 \cdot 3$ & $1089 \cdot 1$ & $\begin{array}{l}1369 \cdot 3 \\
1234 \cdot 4\end{array}$ & $\begin{array}{l}1559 \cdot 3 \\
1438 \cdot 0\end{array}$ & $733 \cdot 2$ & $\begin{array}{l}215(s), 2 \cdot 40(s), 3 \cdot 58(s) \\
7 \cdot 15(d), 8.40(d)\end{array}$ \\
\hline 4 & $\begin{array}{l}\mathrm{C}_{5} \mathrm{H}_{4} \mathrm{~N}-\mathrm{C}_{2} \mathrm{H}_{5} \\
\text { 4-ethyl pyridine }\end{array}$ & $456 \cdot 8$ & $518 \cdot 9$ & $\begin{array}{l}1092 \cdot 7 \\
1237 \cdot 1\end{array}$ & $\begin{array}{l}1366 \cdot 7 \\
1427 \cdot 2\end{array}$ & $1558 \cdot 2$ & $1730 \cdot 2$ & $\begin{array}{l}1 \cdot 15(t), 2 \cdot 16(s), 2 \cdot 45(q) \\
3 \cdot 50(s), 7 \cdot 10(d), 8 \cdot 35(d)\end{array}$ \\
\hline 5 & $\begin{array}{l}\mathrm{C}_{5} \mathrm{H}_{4} \mathrm{~N}-\mathrm{NH}_{2} \\
\text { 4-Amino pyridine }\end{array}$ & $450 \cdot 2$ & $512 \cdot 0$ & $\begin{array}{l}1087 \cdot 1 \\
1239 \cdot 0\end{array}$ & $\begin{array}{l}1365 \cdot 4 \\
1431 \cdot 2\end{array}$ & $1560 \cdot 4$ & $1735 \cdot 4$ & $\begin{array}{l}2 \cdot 12(s), 3 \cdot 45(s), 5 \cdot 65(b s) \\
6 \cdot 45(d), 7 \cdot 85(d)\end{array}$ \\
\hline 6 & $\begin{array}{l}\mathrm{C}_{5} \mathrm{H}_{4} \mathrm{~N}-\mathrm{C}_{2} \mathrm{H}_{5} \\
\text { 2-Ethyl pyridine }\end{array}$ & $450 \cdot 2$ & $513 \cdot 0$ & $\begin{array}{l}1087 \cdot 1 \\
1233 \cdot 4\end{array}$ & $\begin{array}{l}1365 \cdot 4 \\
1437 \cdot 2\end{array}$ & $1560 \cdot 4$ & $1735 \cdot 4$ & $\begin{array}{l}1.22(t) 2 \cdot 20(s), 2 \cdot 84(q) \\
3 \cdot 52(s), 7 \cdot 20(t), \\
\quad 7.31(d), 7 \cdot 70(t), 8.60(d)\end{array}$ \\
\hline 7 & $\begin{array}{l}\mathrm{C}_{5} \mathrm{H}_{4} \mathrm{~N}-\mathrm{NH}_{2} \\
\text { 2-Amino pyridine }\end{array}$ & $451 \cdot 0$ & $514 \cdot 0$ & $\begin{array}{l}1088 \cdot 2 \\
1233 \cdot 6\end{array}$ & $\begin{array}{l}1367 \cdot 2 \\
1432 \cdot 6\end{array}$ & $1560 \cdot 2$ & $1735 \cdot 2$ & $\begin{array}{l}2 \cdot 18(s), 3 \cdot 54(s), 4 \cdot 67 b s) \\
\quad 6 \cdot 33(s), 6 \cdot 94(t) \\
\quad 7 \cdot 23(t), 7 \cdot 0(t)\end{array}$ \\
\hline
\end{tabular}

Recorded as $\mathrm{KBr}$ discs and values in $\mathrm{cm}^{-1} .{ }^{\#}$ in ppm relative to TMS and solvent used DMSO- $d^{6}$

$$
k_{\mathrm{obs}}=k_{\text {on }}^{\prime}[\mathrm{L}]_{\mathrm{t}}+k_{\mathrm{off}} \text {, }
$$

where $[\mathrm{L}]_{\mathrm{t}}$ is the total concentration of $\mathrm{L}$ present. Values of $k^{\prime}{ }_{\text {on, }}$ the second-order ligation rate constants with respect to free ligand was calculated ${ }^{16}$ from $k_{\text {on }}=k^{\prime}{ }_{\text {on }} / \alpha_{\mathrm{L}}$, where $\alpha_{\mathrm{L}}=K_{\mathrm{d}} /\left(K_{\mathrm{d}}+\left[\mathrm{H}^{+}\right]\right) ; K_{\mathrm{d}}=$ dissociation constant of the ligand.

\section{Results and discussion}

The IR data for bromomethyl(aqua)cobaloxime and bromomethyl(ligand)cobaloxime are presented in table 1. The disappearance of peak at $3072 \mathrm{~cm}^{-1}$ and appearance of peak at $450 \mathrm{~cm}^{-1} v(\mathrm{Co}-\mathrm{N})$ indicate the formation of bromomethyl (pyridine)cobaloxime by replacing $\mathrm{H}_{2} \mathrm{O}$. The characteristic absorption bands due to dimethyl glyoximato ligands in these cobaloximes do not shift largely by the change of axial ligands. This suggests that the strength of the Co-N bonds in the equatorial position is not much affected by the change of the axial ligands because, the Co-N (equatorial) bonds are very strong due to $\mathrm{Co} \rightarrow \mathrm{N}=\mathrm{C} \pi$ bond.

These results can be interpreted as follows. The coordination of more electron donating base to Co(III) causes the increase in electron density in Co(III) which facilitates the back donation from
Co(III) to the nitrogen atoms of dimethyl glyoximato ligands resulting in the increase in electron densities in $\mathrm{C}=\mathrm{N}$ and $\mathrm{N}-\mathrm{O}$ bonds. The increase in electron density in $\mathrm{N}-\mathrm{O}$ bonds causes the stronger hydrogen bridges of $\mathrm{O}-\mathrm{H}$... $\mathrm{O}$ and higher frequency shifts of $\mathrm{N}-\mathrm{O}$ stretching vibrations. The facilitated back donation from cobalt to nitrogen atoms of dimethylglyoxime lowers the $\mathrm{C}=\mathrm{N}$ stretching frequency. As the electron donating power of ligand increases, the binding constant $\left(K_{\text {eq }}\right)$ increases and the binding constants $\left(K_{\text {eq }}\right)$ follows the order 4- $\mathrm{NH}_{2} \mathrm{Py}>4$-EtPy $>4-\mathrm{MePy}>\mathrm{Py}$.

The electronic spectra of bromomethyl(aqua) cobaloximes in $\mathrm{MeOH}$ shows spin allowed ${ }^{1} \mathrm{~A}_{1} \mathrm{~g} \rightarrow{ }^{1} \mathrm{~T}_{1} \mathrm{~g}$ transition ${ }^{17}$ in the region $\sim 22,000 \mathrm{~cm}^{-1}$ due to $\mathrm{CH}_{2} \mathrm{Br}^{-}$to $\mathrm{Co}$ (III) $\sigma$ donation. This band disappears or the intensity drastically decreases in bromomethyl (ligand) cobaloximes. The electronic spectra of $\mathrm{BrCH}_{2} \mathrm{Co}(\mathrm{DH})_{2} \mathrm{OH}_{2}, \mathrm{BrCH}_{2} \mathrm{Co}(\mathrm{DH})_{2} \mathrm{Py}$, $\mathrm{SCNCo}(\mathrm{DH})_{2} \mathrm{Py}$ and $\mathrm{CN} \mathrm{Co}(\mathrm{DH})_{2} \mathrm{Py}$ are compared. In case of $\mathrm{BrCH}_{2}$ complexes only intense absorbance band at $22,000 \mathrm{~cm}^{-1}$ is observed. No band observed for $\mathrm{SCN}$ or $\mathrm{CN}$ complexes indicating the band at $22,000 \mathrm{~cm}^{-1}$ is due to $\mathrm{CH}_{2} \mathrm{Br}^{-}$to $\mathrm{Co}$ (III) $\sigma$ donation. The charge-transfer spectra of the trans $\left[\mathrm{BrCH}_{2} \mathrm{Co}(\mathrm{DH})_{2} \mathrm{~L}\right]$ complexes show a band at $41,000 \mathrm{~cm}^{-1}$ due to intra-ligand $\pi-\pi^{*}$ transition of 
Table 2. ${ }^{13} \mathrm{C}_{\mathrm{NMR}}$ Spectral data for bromomethyl(ligand)cobaloximes $-\left[\mathrm{BrCH}_{2} \mathrm{Co}(\mathrm{DH})_{2} \mathrm{~L}\right]$.

\begin{tabular}{|c|c|c|c|c|c|c|c|c|}
\hline \multirow{2}{*}{$\begin{array}{l}\text { Sl. } \\
\text { no. }\end{array}$} & \multirow{2}{*}{$\begin{array}{c}\text { Complex } \\
{\left[\mathrm{BrCH}_{2} \mathrm{Co}(\mathrm{DH})_{2} \mathrm{~L}\right]} \\
\text { where } \mathrm{L}=\end{array}$} & \multirow[b]{2}{*}{ eq $\mathrm{CH}_{3}$} & \multirow[b]{2}{*}{$\mathrm{C}=\mathrm{N}$} & \multirow[b]{2}{*}{$\mathrm{CH}_{2} \mathrm{Br}$} & \multicolumn{4}{|c|}{ Pyridine carbons } \\
\hline & & & & & $\mathrm{C}_{2}, \mathrm{C}_{6}$ & $\mathrm{C}_{3}, \mathrm{C}_{5}$ & $\mathrm{C}_{4}$ & $\mathrm{R}$ \\
\hline 1 & Water & 13.10 & 149.92 & 41.42 & - & - & - & - \\
\hline 2 & $\mathrm{C}_{5} \mathrm{H}_{5} \mathrm{~N}$ pyridine & $12 \cdot 95$ & $150 \cdot 96$ & $46 \cdot 10$ & $153 \cdot 81$ & $130 \cdot 42$ & $141 \cdot 60$ & - \\
\hline 3 & $\mathrm{C}_{5} \mathrm{H}_{4} \mathrm{~N}-\mathrm{CH}_{3}$ 4-methyl pyridine & 12.78 & $150 \cdot 34$ & $44 \cdot 80$ & $153 \cdot 62$ & $129 \cdot 80$ & $154 \cdot 86$ & $22 \cdot 34\left(\mathrm{CH}_{3}\right)$ \\
\hline 4 & $\begin{array}{l}\mathrm{C}_{5} \mathrm{H}_{4} \mathrm{~N}-\mathrm{C}_{2} \mathrm{H}_{5} \\
\text { 4-Ethyl pyridine }\end{array}$ & $12 \cdot 60$ & $150 \cdot 68$ & 45.92 & $153 \cdot 40$ & $128 \cdot 64$ & $155 \cdot 70$ & $\begin{array}{l}28.70\left(\mathrm{CH}_{2}\right) \\
13.25\left(\mathrm{CH}_{3}\right)\end{array}$ \\
\hline 5 & $\mathrm{C}_{5} \mathrm{H}_{4} \mathrm{~N}-\mathrm{NH}_{2}$ 4-amino pyridine & $12 \cdot 32$ & $150 \cdot 94$ & $46 \cdot 20$ & $153 \cdot 12$ & $108 \cdot 40$ & $158 \cdot 30$ & - \\
\hline
\end{tabular}

Dissolved in DMSO- $d^{6}$ and values in ppm relative to TMS

Table 3. Psuedo first order rate constants at different $\mathrm{pH}$ for the formation and dissociation of $\left[\mathrm{BrCH}_{2} \mathrm{Co}\left(\mathrm{DH}_{2}\right) \mathrm{OH}_{2}\right]$ at $25^{\circ} \mathrm{C}$ in aqueous solution, ionic strength $1.0 \mathrm{M} \mathrm{KCl}$.

\begin{tabular}{|c|c|c|c|c|c|c|c|c|c|}
\hline \multicolumn{3}{|c|}{$k_{\mathrm{obs}}\left(\mathrm{s}^{-1}\right)$} & \multicolumn{3}{|c|}{$k_{\text {off }}\left(\mathrm{s}^{-1}\right)$} & \multicolumn{4}{|c|}{$k_{\mathrm{obs}}\left(\mathrm{s}^{-1}\right)$} \\
\hline$p \mathrm{H}$ & Py & MePy & $\mathrm{pH}$ & Py & MePy & $C: L$ & {$[\mathrm{~L}] \times 10^{-2}$} & $\mathrm{Py} \times 10^{-2}$ & $\mathrm{MePy} \times 10^{-3}$ \\
\hline \multirow{3}{*}{$4 \cdot 0$} & \multirow{3}{*}{$8.00 \times 10^{-3}$} & \multirow{3}{*}{$7.00 \times 10^{-3}$} & \multirow{3}{*}{$2 \cdot 0$} & \multirow{3}{*}{$1.54 \times 10^{-2}$} & \multirow{3}{*}{-} & $1: 10$ & 1.00 & 0.8 & 1.53 \\
\hline & & & & & & $1: 15$ & 1.50 & $1 \cdot 10$ & $2 \cdot 50$ \\
\hline & & & & & & $1: 20$ & $2 \cdot 00$ & 1.47 & 3.93 \\
\hline \multirow[t]{2}{*}{$4 \cdot 5$} & \multirow[t]{2}{*}{$1.20 \times 10^{-2}$} & \multirow[t]{2}{*}{$1.10 \times 10^{-2}$} & \multirow[t]{2}{*}{$2 \cdot 5$} & \multirow[t]{2}{*}{$1.04 \times 10^{-2}$} & \multirow[t]{2}{*}{-} & $1: 25$ & $2 \cdot 50$ & 1.71 & $6 \cdot 29$ \\
\hline & & & & & & $1: 30$ & $3 \cdot 00$ & 1.92 & - \\
\hline $5 \cdot 0$ & $1.78 \times 10^{-2}$ & $1.20 \times 10^{-2}$ & $3 \cdot 0$ & $8.20 \times 10^{-3}$ & $9.00 \times 10^{-3}$ & $1: 35$ & $3 \cdot 50$ & $2 \cdot 10$ & - \\
\hline $5 \cdot 5$ & $2.00 \times 10^{-2}$ & $1.22 \times 10^{-2}$ & $3 \cdot 5$ & - & $7.00 \times 10^{-3}$ & $k_{\text {on }}^{\prime}$ & & 0.0052 & 0.0031 \\
\hline $6 \cdot 0$ & $2 \cdot 10 \times 10^{-2}$ & - & 4.0 & - & $6.00 \times 10^{-3}$ & $\alpha$ & & 0.0299 & 0.0074 \\
\hline $6 \cdot 5$ & $2 \cdot 14 \times 10^{-2}$ & - & & & & $\underset{\left(\mathrm{dm}^{3} \mathrm{n}\right.}{k_{\mathrm{on}}}$ & $\left.1^{-1} s^{-1}\right)$ & $0 \cdot 1739$ & 0.4189 \\
\hline
\end{tabular}

$\left[\mathrm{BrCH}_{2} \mathrm{Co}\left(\mathrm{DH}_{2}\right) \mathrm{OH}_{2}\right] 1.25 \times 10^{-3}$ and $[\mathrm{L}]_{\mathrm{T}} 1.25 \times 10^{-2}$

the coordinated dimethylglyoxime. ${ }^{18} \mathrm{~A}$ band occurring at $27,500 \mathrm{~cm}^{-1}$ is assigned to the pyridine $\rightarrow \mathrm{Co}\left(\right.$ LMCT) and that at $46,000 \mathrm{~cm}^{-1}$ is to the $d \pi(\mathrm{Co}) \rightarrow \pi^{*}$ (DH) (MLCT) transition. ${ }^{19}$ The $\sigma$ $(\mathrm{DH}) \rightarrow \sigma^{*} \mathrm{Co}$ (LMCT) is masked by the intense short wavelength bands of bromomethyl(ligand) cobaloximes. $^{20}$

In all these complexes ${ }^{1} \mathrm{H}$ NMR shows a sharp singlet at around $2 \cdot 10-2 \cdot 20 \mathrm{ppm}$ corresponding to the equatorial methyl protons of dimethyl glyoxime and a singlet $\sim 3.50 \mathrm{ppm}$ corresponding to $\mathrm{CH}_{2} \mathrm{Br}$ protons. In the pyridine free ligand the $\mathrm{H}_{2}\left(\mathrm{H}_{6}\right)$, $\mathrm{H}_{3}\left(\mathrm{H}_{5}\right)$ ) and $\mathrm{H}_{4}$ proton chemical shifts appear at $7.60 \mathrm{ppm}, 7.25 \mathrm{ppm}$ and $7.75 \mathrm{ppm}$, respectively. Coordination of pyridine to $\mathrm{Co}(\mathrm{III})$ center of bromomethylcobaloxime render the $\mathrm{H}_{2}\left(\mathrm{H}_{6}\right)$ protons shift to farthest down field and observed at $8.50 \mathrm{ppm}$. The chemical shifts observed at $7.42 \mathrm{ppm}$ and $7.85 \mathrm{ppm}$ for $\mathrm{H}_{3}\left(\mathrm{H}_{5}\right)$ and $\mathrm{H}_{4}$ protons respectively. All the other complexes follows the same trend of downfield shift and the data are presented in table 1. In the ${ }^{\mathrm{I} 3} \mathrm{C}$ NMR spectra, the peak around
$13.0 \mathrm{ppm}$ corresponds to the four equatorial methyl groups of dimethyl glyoxime as shown in table 2 . The $\mathrm{C}=\mathrm{N}$ group chemical shifts observed around $150.0 \mathrm{ppm}$. The chemical shifts for the pyridine and substituted pyrdines are in the aromatic region as expected and observed in the down field when compared to free ligands.

Figure 1 shows the association kinetics and as the time increases the absorbance decreases indicating the formation of complex. Figure 2 shows the increase in absorbance with increase in time, this is because the complex $\left[\mathrm{BrCH}_{2} \mathrm{Co}(\mathrm{DH})_{2} \mathrm{~L}\right]$ dissociates and forms $\left[\mathrm{BrCH}_{2} \mathrm{Co}(\mathrm{DH})_{2}\left(\mathrm{OH}_{2}\right)\right]$ with increase in time.

If we compare the $\left(K_{\text {eq }}\right)$ binding constants ${ }^{21,22}$ of various ligands binding with $\mathrm{BrCH}_{2} \mathrm{Co}(\mathrm{DH})_{2} \mathrm{OH}_{2}$ they are in the order $\mathrm{K}_{\mathrm{OH}}<\mathrm{K}_{2 \text {-EtPy }}<\mathrm{K}_{2}-\mathrm{NH}_{2} \mathrm{Py}<\mathrm{K}_{\mathrm{py}}<$ $\mathrm{K}_{4 \text {-Mepy }}<\mathrm{K}_{4-\text {-EtPy }}<\mathrm{K}_{4}-\mathrm{NH}_{2} \mathrm{Py}<\mathrm{K}_{\text {lmd }}<\mathrm{K}_{1 \text {-Melmd }}<<\mathrm{K}_{\mathrm{CN}}$ has shown in table 3 . This trend is in accordance with the basicity. Except 2-EtPy and 2- $\mathrm{NH}_{2}$ Py all other ligands binding to $\mathrm{BrCH}_{2} \mathrm{Co}(\mathrm{DH})_{2} \mathrm{OH}_{2}$ follow the bascitiy order. Though 2-EtPy and 2- $\mathrm{NH}_{2} \mathrm{Py}$ are 


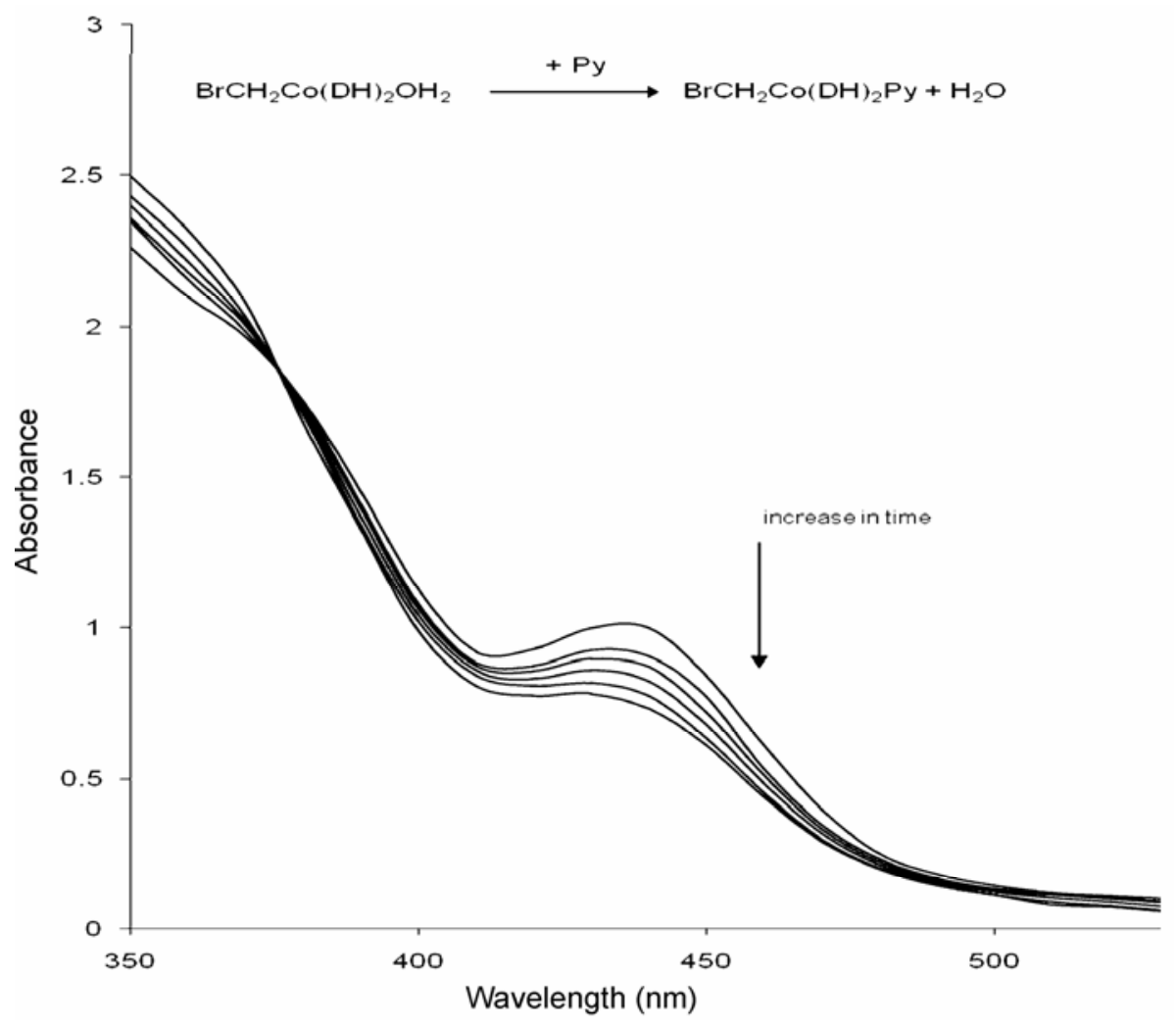

Figure 1. UV-Visible scan: Kinetics of association of $\mathrm{BrCH}_{2} \mathrm{Co}(\mathrm{DH})_{2} \mathrm{OH}_{2}$ with pyridine at $p \mathrm{H}=4.0$ and $25^{\circ} \mathrm{C}$. Isosbestic point $=380 \mathrm{~nm}$.

more basic than Pyridine, they form less stable complexes than Pyridine. This is due to steric hindrance caused by the substituent (ethyl or amino group) at $\mathrm{C}_{2}$ of Pyridine. In addition, much higher stability of $\mathrm{CN}^{-}$compared to pyridine and imidazole is due to more basic and $\pi$ accepting ability of cyanide than imidazole and pyridine.

The plot of pseudo first order rate constant $k_{\mathrm{obs}}$, against ligand concentration was linear with very small intercept indicating that some dissociation accompanies the complex formation, and $k_{\text {off }}$ increases with increase in $p \mathrm{H}$.

When $k_{\text {obs }}$ verses the concentration of the entering ligand were plotted, the $k_{\text {obs }}$ increases with increasing ligand concentration over the whole ligand concentration range.

$$
\begin{aligned}
& \mathrm{BrCH}_{2} \mathrm{Co}(\mathrm{DH})_{2} \mathrm{H}_{2} \mathrm{O} \underset{\hat{k}_{\mathrm{on}}}{\stackrel{k_{\text {off }}}{\rightleftharpoons}} \\
& \mathrm{BrCH}_{2} \mathrm{Co}(\mathrm{DH})_{2}+\mathrm{H}_{2} \mathrm{O} \\
& {\left[\mathrm{BrCH}_{2} \mathrm{Co}(\mathrm{DH})_{2}\right]+\mathrm{L} \stackrel{K_{\mathrm{eq}}}{\rightleftharpoons}\left[\mathrm{BrCH}_{2} \mathrm{Co}(\mathrm{DH})_{2} \mathrm{~L}\right] . }
\end{aligned}
$$

Evidence for the existence of pentacoordinate species among alkyl cobinamides and alkylcobaloximes is given by Firth et al ${ }^{23,24}$ Because of the delocalization of electron density from unsaturated equatorial ligand (DMG) on to the Co(III) center. This induces partial $\mathrm{Co}(\mathrm{II})$ character and account for higher kinetic lability. All this support the D (dissociation) mechanism shown in above equation.

Figure 3 shows the pseudo-first order rate constant for the formation $\left(k_{\mathrm{obs}}\right)$ and dissociation $k_{\mathrm{off}}$ as a function of $p \mathrm{H}$. For pyridine $k_{\mathrm{obs}}$ increase slowly up to $5.5 \mathrm{pH}$ and then steady and not much increase in $k_{\text {obs }}$ with increase in $p \mathrm{H}$. Similar trends were observed in the binding studies, as the $p \mathrm{H}$ increases $K_{\text {eq }}$ increases and at higher $p \mathrm{H} K_{\text {eq }}$ is almost constant.

Second order rate constants $k_{\text {on }}^{\prime}$ have been calculated to compare the rate constants of pyridine and 4-methyl pyridine for the formation of complexes with $\mathrm{BrCH}_{2} \mathrm{Co}(\mathrm{DH})_{2} \mathrm{OH}_{2}$ from the slopes of the pseudo-first order rate constants as a function of ligand concentration. The $\mathrm{pH}$ independent second order rate constants were caluculated by dividing 


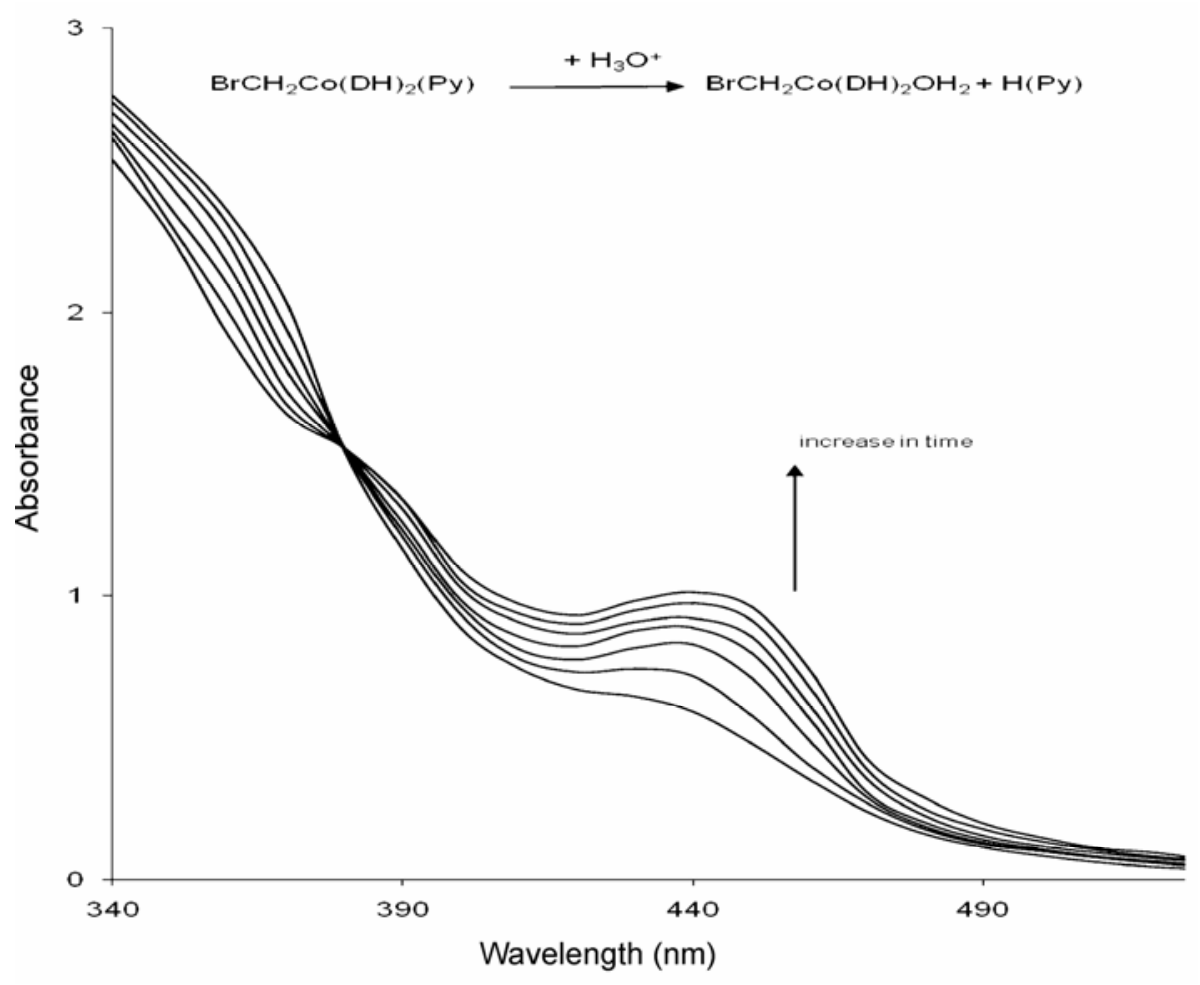

Figure 2. UV-Visible scan: Kinetics of dissociation of $\mathrm{BrCH}_{2} \mathrm{Co}(\mathrm{DH})_{2} \mathrm{Py}$ into $\mathrm{BrCH}_{2} \mathrm{Co}(\mathrm{DH})_{2} \mathrm{OH}_{2}$ at $p \mathrm{H}=2 \cdot 5$. Isosbestic point $=380 \mathrm{~nm}$.

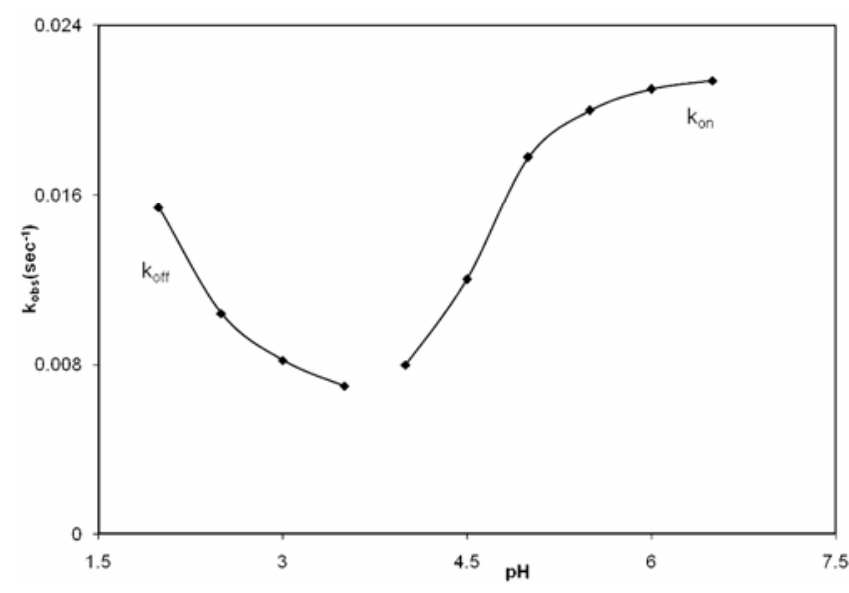

Figure 3. Dependance of $p \mathrm{H}$ on pseudo-first order rate constants for the formation and dissociation of $\left[\mathrm{BrCH}_{2} \mathrm{Co}(\mathrm{DH})_{2}(\mathrm{Py})\right]$ at $250^{\circ} \mathrm{C}$ and ionic strength $1.0 \mathrm{M}$ $\mathrm{KCl}$.

$k^{\prime}$ on with $\alpha_{\mathrm{L}}\left(k_{\text {on }}=k^{\prime}{ }_{\text {on }} / \alpha_{\mathrm{L}}\right)$ where $\alpha_{\mathrm{L}}$ is the degree of dissociation of the ligands at a given $p \mathrm{H}$. The $k_{\mathrm{on}}$ of $4-\mathrm{MePy}>\mathrm{Py}$. This order of $k_{\mathrm{on}}$ is in accordance with the basicity of the ligands.

\section{DNA binding studies}

\subsection{Absorption studies}

The application of electronic absorption spectroscopy in DNA-binding studies is one of the most useful techniques. ${ }^{25,26}$ Complex binding with DNA in the groove mode usually results in hypochromism and bathochromism. The extent of the hypochromism commonly parallels the groove binding strength. The absorption spectra of the complex $\left[\mathrm{CH}_{2} \mathrm{BrCo}\right.$ $\left.(\mathrm{DH})_{2}\left(\mathrm{OH}_{2}\right)\right]$ in the absence and presence of calf thymus DNA in tris buffer are illustrated in figure 4. In the UV region, the intense absorption bands observed for $\mathrm{Co}(\mathrm{III})$ complexes are attributed to intraligand $\pi-\pi^{*}$ transition of the coordinated groups. Addition of increasing amounts of CT DNA results in hypochromism and a moderate bathochromic shift of the UV spectrum of the complex $\left[\mathrm{CH}_{2} \mathrm{BrCo}(\mathrm{DH})_{2}\left(\mathrm{OH}_{2}\right)\right]$. To quantitatively determine binding strength of the Co(III) complex, the intrinsic binding constants $K_{\mathrm{b}}$ of the complex with CT DNA were determined according to below given equation $^{27}$ Through a plot of [DNA] $/\left(\varepsilon_{\mathrm{a}}-\varepsilon_{\mathrm{f}}\right)$ vs [DNA], 
where [DNA] is the concentration of DNA in base pairs. Where $\varepsilon_{\mathrm{a}}$ is the extinction coefficient observed for the MLCT absorption band at given DNA concentration, $\varepsilon_{\mathrm{f}}$ is the extinction coefficient of the complex in the absence of DNA, $\varepsilon_{\mathrm{b}}$ is the extinction coefficient of the complex fully bound to DNA. In the plots [DNA] $/\left(\varepsilon_{\mathrm{b}}-\varepsilon_{\mathrm{f}}\right)$ vs. [DNA], $K_{\mathrm{b}}$ is given by the ratio of slope to intercept. Intrinsic binding constants $K_{\mathrm{b}}$ of $1.8 \times 10^{4} \mathrm{M}^{-1}$ were obtained from the decay of the absorbance. The binding constants indicate that the complex binds strongly to the DNA.

$[\mathrm{DNA}] /\left(\varepsilon_{\mathrm{a}}-\varepsilon_{\mathrm{f}}\right)=[\mathrm{DNA}] /\left(\varepsilon_{\mathrm{b}}-\varepsilon_{\mathrm{f}}\right)+1 /\left(K\left(\varepsilon_{\mathrm{b}}-\varepsilon_{\mathrm{f}}\right)\right)$

Binding of $\mathrm{CH}_{2} \mathrm{BrCo}(\mathrm{DH})_{2} \mathrm{Py}$ with CT-DNA also measured and compared with aqua complex. $\mathrm{CH}_{2} \mathrm{BrCo}(\mathrm{DH})_{2} \mathrm{Py}$ binds strongly $\left(\mathrm{K}=1.03 \times 10^{5} \mathrm{M}^{-1}\right)$ to DNA when compared to aqua complex. This indicates that the pyridine ligand may partially intercalate in between base pairs.

\subsection{Fluorescence spectroscopic studies}

The complex $\left[\mathrm{CH}_{2} \mathrm{BrCo}(\mathrm{DH})_{2}\left(\mathrm{OH}_{2}\right)\right]$, exhibits luminescence in tris buffer $(p \mathrm{H} \mathrm{7.0)}$ at room temperature with a maximum at $387 \mathrm{~nm}$. Binding of the complex to DNA was found to increase the fluorescence intensity. The emission spectra of the complex in the absence and presence of CT DNA are shown in figure (5).

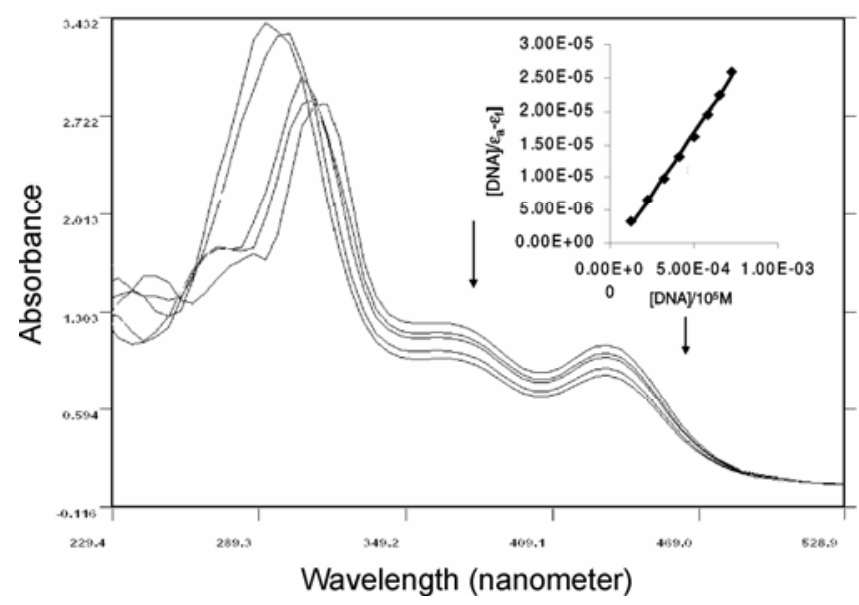

Figure 4. Absorption spectra of complex in tris- $\mathrm{HCl}$ buffer on addition of CT DNA in absence (top) and presence of CT DNA (lower) the $[\mathrm{Co}]=10 \mu \mathrm{m}$; [DNA] $=$ $0-126 \mu \mathrm{m}$. Inset: plots of relative intensity vs [DNA]/[Co] for the titration of DNA with Co(III) complex.
This observation is further supported by the emission quenching experiments using $\left[\mathrm{Fe}(\mathrm{CN})_{6}\right]^{4-}$ as quencher. The ion $\left[\mathrm{Fe}(\mathrm{CN})_{6}\right]^{4-}$ distinguish between differentially bound Co(III) species and positively charged free complex ions readily as the ions are quenched by $\left[\mathrm{Fe}(\mathrm{CN})_{6}\right]^{4}$. The complex bound to DNA can be protected from the quencher, because highly negatively charged $\left[\mathrm{Fe}(\mathrm{CN})_{6}\right]^{4}$ would be repelled by the negative DNA phosphate backbone, hindering the quenching of the emission of the bound complex. The method essentially consists of

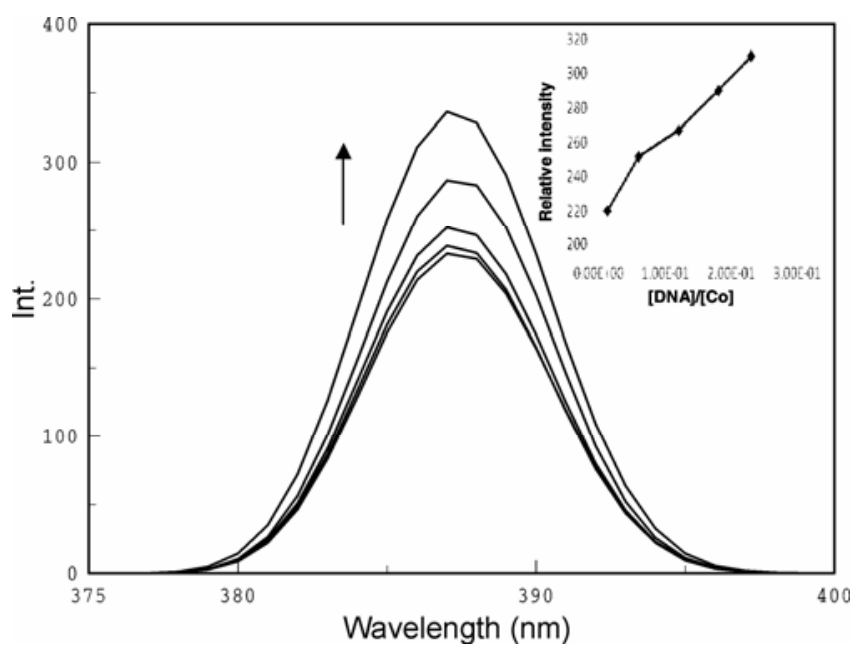

Figure 5. Fluorescence Emission spectra of complex in tris- $\mathrm{HCl}$ buffer fluorescence intensity increases on increasing CT DNA concentrations $(5 \mu \mathrm{l}, 10 \mu \mathrm{l}, 15 \mu \mathrm{l}$, $20 \mu \mathrm{l}$ of DNA addition). Inset: Plots of relative integrated emission intensity vs [DNA]/[Co].

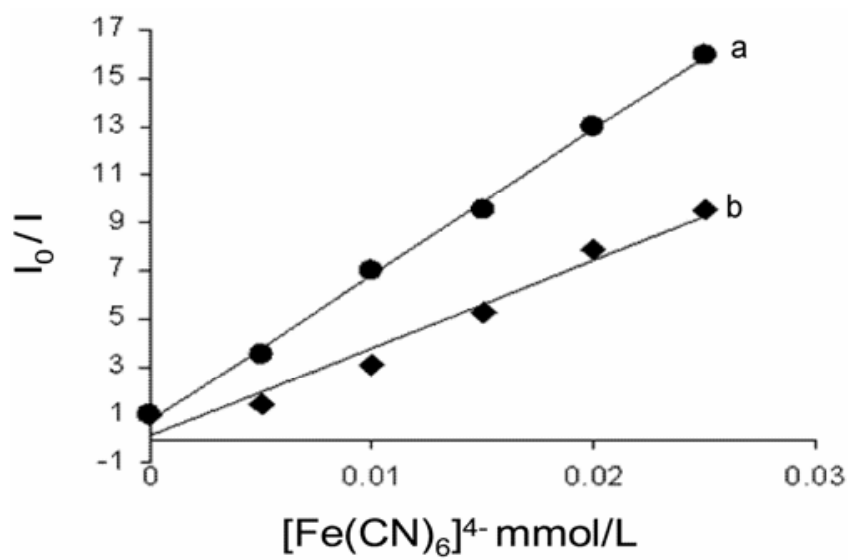

Figure 6. Emission quenching of $\mathrm{Co}(\mathrm{III})$ complex + DNA with ferrocyanide (a), quenching of $\mathrm{Co}$ (III) complex along with ferrocyanide (b), $[\mathrm{Co}]=2 \mu \mathrm{mol} / \mathrm{cm}^{-3}$, $[\mathrm{DNA}] /[\mathrm{Co}]=40$. 
titrating a given amount of DNA-metal complex with increasing the concentration of $\left[\mathrm{Fe}(\mathrm{CN})_{6}\right]^{4-}$. The ferro-cyanide quenching curves for this complex in the presence and absence of CT DNA are shown in figure 6. The complex is protected by DNA hence quenching is low in presence of DNA. The absorption and fluorescence spectroscopy studies determine the binding of complex with DNA.

\section{Conclusions}

The binding of Pyridines to $\mathrm{BrCH}_{2} \mathrm{Co}(\mathrm{DH})_{2} \mathrm{OH}_{2}$ follow the basicitiy order. 2-Et-Pyridine and 2- $\mathrm{NH}_{2}-$ Pyridine are more basic than pyridine but they form less stable complexes due to steric hindrance of the substituent at $\mathrm{C}_{2}$ of Pyridine. D mechanism was proposed for the substitution of $\mathrm{H}_{2} \mathrm{O}$ by $\mathrm{L}$. The binding of $\mathrm{BrCH}_{2} \mathrm{Co}(\mathrm{DH})_{2} \mathrm{OH}_{2}$ to DNA was monitored by absorbance and fluorescence spectroscopy techniques. This complex binds to DNA moderately through groove mode.

\section{Acknowledgement}

One of the authors SSN gratefully acknowledges the University Grants Commission (UGC), New Delhi for financial support.

\section{References}

1. Toraya T, Krodel E, Mildran A S and Abeles R H 1979 Biochemistry 18417

2. Pratt J M 1985 Chem. Soc. Rev. 161

3. Hay B P and Finke R G 1987 J. Am. Chem. Soc. 109 8012

4. Randaccio L, Bresciani-Pahor N, Zangrando E and Marzilli L G 1989 Chem. Soc. Rev. 16229

5. Bresciani-Pahor N, Forcolin M, Marzilli L G, Randaccio L, Summers M F and Toscano P J 1985 Coord. Chem. Rev. 631
6. Kirn S H, Chen H L, Feilchenfield $\mathrm{N}$ and Halpern J 1988 J. Am. Chem. Soc. 1103120

7. Randaccio L 1994 Inorg. Chim. Acta. 61235

8. Geremia S, Randaccio L, Dreos R and Tauzher G 1995 Chim. Ital. 12595

9. Asaro F, Dreos R, Geremia S, Nardin G, Pellizer G, Randaccio L, Tauzher G and Vuano S 1997 J. Organomet. Chem. 548211

10. Sridhar V and Satyanarayana S 2000 Proc. Indian Acad. Sci. (Chem. Sci.) 112579

11. Sridhar V and Satyanarayana S 2001 Ind. J. Chem. A40 165

12. Sudarshan Reddy D, Ravi Kumar Reddy N, Sridhar V and Satyanarayana S 2002 Proc. Indian Acad. Sci. (Chem. Sci.) $\mathbf{1 1 4} 1$

13. Sridhar V, Sudarshan Reddy D, Ravi Kumar Reddy N and Satyanarayana S 2002 Proc. Indian Acad. Sci. (Chem. Sci.) 11411

14. Brown K L 1986 Organo metallic synthesis (eds) R B King and J J Eisch (Amestardam: Elseiver) 3186

15. Brown K L 1979 Inorg. Chim. Acta. 37513

16. Marques H M, Egan T J, Marsh J H, Mellor J R and Munro O K 1989 Inorg. Chim. Acta 166249

17. Lever A B P 1968 Inorganic electronic spectroscopy (Amestardam: Elseiver)

18. Yamano Y, Masuda I and Shimura K 1977 Bull. Chem. Soc. Japan 441581

19. Brown K L and Satyanarayana S 1992 Inorg. Chem Acta 201113

20. Garlatti R D, Tauzher G and Costa G 1984 Inorg. Chim. Acta 82197

21. Ablov A V, Filippov M P and Samus N M 1968 Dokl. Akad. Nauk USSR 133575

22. Brown K L and Satyanarayana S $1992 \mathrm{~J}$. Am. Chem. Soc. 1145674

23. Brown K L and Kallen R G 1972 J. Am. Chem. Soc. 941894

24. Firth R A, Hill H A O, Mann B E, Pratt J M, Thorp R G and Williams R J P 1968 J. Chem. Soc. A 2419

25. Kelly J M, Tossi A B, McConnell D J and OhUigin C 1985 Nuclic Acids Res. 136017

26. Tysoe S A, Morgan R J, Baker A D and Strekas T C 1993 J. Phys. Chem. 971707

27. Wolfe A, Shimer G H and Meehan T 1987 Biochemistry 266392 